\title{
UPAYA MENINGKATKAN MINAT BELAJAR ANAK BERKEBUTUHAN KHUSUS PADA KELAS II SDN UNGGULAN MELALUI METODE FULL INCLUSION
}

\begin{abstract}
Aisah, S. Pd.
SD N Unggulan Kuningan

Pengutipan: Aisah. (2019). Upaya meningkatkan minat belajar anak berkebutuhan khusus pada kelas II SDN Unggulan melalui metode inklusi penuh. Pedagogi: Jurnal Penelitian Pendidikan, 6 (1), hlm 1-9.

Diajukan: 29-01-2019

Diterima: 30-05-2019

Diterbitkan: 31-05-2019

ABSTRAK

Tujuan penelitian tindakan ini adalah untuk meningkatkan minat belajar siswa Anak Berkebutuhan Khusus (ABK) dengan metode Inklusi Penuh (Full Inclusion) dalam mata pelajaran Matematika Kelas II SD N Unggulan Kuningan. Penelitian ini menggunakan penelitian tindakan (action research) sebanyak 2 siklus. Setiap putaran terdiri dari empat tahap yaitu: rancangan, kegiatan dan pengamatan, refleksi, serta revisi. Sasaran penelitian ini adalah siswa Kelas II A. Data yang diperoleh berupa hasil tes formatif dan hasil observasi kegiatan belajar mengajar. Berdasarkan hasil analisis didapatkan bahwa prestasi belajar siswa mengalami peningkatan rata-rata nilai dari siklus 1 sampai siklus 2 yaitu, siklus 1 adalah $66 \%$, dan siklus 2 adalah $95 \%$. Sedangkan peningkatan hasil belajar siswa ABK, ditemukan bahwa semua siswa ABK mengalami peningkatan hasil belajar. Kesimpulan dari penelitian ini adalah bahwa pemakaian metode pembelajaran Full Inclusion memberikan pengaruh yang signifikan terhadap peningkatan minat belajar siswa ABK.
\end{abstract}

Kata Kunci: Full Inclusion, ABK, Minat Belajar, Hasil Belajar 
Aisah, S. Pd.

Upaya Meningkatkan Minat Belajar Anak Berkebutuhan Khusus Pada Kelas II SDN

Unggulan Melalui Metode Inklusi Penuh

\section{PENDAHULUAN}

Pendidikan merupakan salah satu wahana perluasan akses dan mobilitas sosial dalam masyarakat, baik secara horizontal maupun secara vertikal. Selain itu, pendidikan menjadi tolok ukur kemajuan suatu bangsa. Pendidikan bagi anak berkebutuhan khusus semakin hari semakin berkembang. Perubahan yang cukup signifikan dilakukan baik dari pemerintah, sekolah, siswa bukan berkebutuhan khusus, orang tua, dan masyarakat pada umumnya. Pemerintah melalui landasan yuridis yang tercermin dalam pasal 31 ayat 1 UUD 1945 disebutkan bahwa "Setiap warga negara berhak mandapatkan pendidikan". Selain itu, pada Permendiknas Nomor 70 Tahun 2009 disebutkan bahwa "Pendidikan untuk semua" sebagai dasar terkait penyelenggaraan pendidikan inklusif bagi anak berkebutuhan khusus dan penerimaan oleh sekolah umum serta masyarakat yang membuat anak berkebutuhan khusus memiliki kesempatan yang lebih luas dalam mendapatkan pendidikan seperti anak normal yang lain dan mampu mengembangkan potensi sesuai kebutuhannya.

SDN Unggulan Kuningan sebagai salah satu Sekolah Penyelenggara Pendidikan Inklusi (SPPI) di Kabupaten Kuningan yang sudah dilaksanakan sejak tahun 2010. Hal tersebut mengartikan bahwa sekolah ini mempunyai perbedaan dengan sekolah reguler yang notabene bukan SPPI. Proses pembelajaran untuk anak berkebutuhan khusus (ABK) menggunakan kurikulum sekolah reguler umum, dengan jumlah tenaga pendidik 19 orang Guru Kelas dan Bidang Studi yang mendapat bimbingan teknik inklusif. Artinya, guru terkait tentunya paham betul mengenai cara penanganan ABK dalam pembelajaran reguler. Pada awal pembentukanya, sekolah ini memiliki tenaga Psikolog khusus yang diperuntukkan bagi peserta didik berkebutuhan khusus. Namun sekarang, mempersepsikan pendidikan inklusif sama dengan sistem integrasi, sehingga anak yang menyesuaikan dengan sistem sekolah. Anak berkebutuhan khusus diperlakukan sama seperti peserta didik lainnya di sekolah tersebut, yaitu tanpa mendapat pelayanan yang khusus sesuai kebutuhannya. Sekolah belum menyediakan guru tenaga pendidik khusus. Malah ada juga sekolah yang masih pilih-pilih dalam menerima siswa berkebutuhan khusus. Pembinaan terhadap tenaga pendidik dan kependidikan mengarah pada pendidikan inklusif. Guru belum mampu menyusun program pembelajaran individual berdasarkan identifikasi dan assesmen. Selain itu, juga belum ada sistem penilaian yang cocok untuk menilai kemajuan hasil belajar siswa berkebutuhan khusus.

Belajar merupakan tindakan dan perilaku siswa yang kompleks. Sebagai tindakan, maka belajar hanya dialami, dilakukan, dan dihayati oleh siswa itu sendiri. Siswa adalah penentu terjadi atau tidaknya proses belajar. Artinya, proses belajar terjadi berkat siswa memperoleh sesuatu yang ada di lingkungan baik itu berupa keadaan alam, benda-benda, hewan, tumbuh-tumbuhan, manusia, atau hal-hal yang dijadikan bahan belajar (Dimyati \& Mudjiono, 1997: 7). Teori kognitif mendefinisikan belajar sebagai perubahan persepsi dan pemahaman yang tidak selalu dapat terlihat sebagai tingkah laku yang tampak sehingga dapat diasumsikan bahwa proses belajar akan berjalan dengan baik jika materi pelajaran atau informasi baru beradaptasi dengan struktur kognitif yang telah dimiliki seseorang (Budiningsih, 2005: 51).

Minat dapat menjadi sebab sesuatu kegiatan dan sebagai hasil dari keikutsertaan dalam suatu kegiatan. Oleh karena itu, minat belajar adalah kecenderungan hati untuk belajar untuk mendapatkan informasi, pengetahuan, kecakapan melalui usaha, pengajaran atau pengalaman (Hardjana, 1994). Menurut Gie (1998), minat berarti sibuk, tertarik, atau terlihat sepenuhnya dengan sesuatu kegiatan karena menyadari pentingnya kegiatan itu. Minat belajar membentuk sikap akademik tertentu yang bersifat sangat pribadi pada setiap siswa. Maka dari itu, minat belajar harus ditumbuhkan sendiri oleh masing-masing siswa. Pihak lainnya hanya memperkuat dan menumbuhkan minat atau untuk memelihara minat yang telah dimiliki seseorang (Loekmono, 1994). Apabila minat belajar didapatkan, pada gilirannya akan 
menumbuhkan konsentrasi atau kesungguhan dalam belajar (Sudarmono, 1994). Minat berkaitan dengan nilai-nilai tertentu. Perenungan terhadap nilai-nilai dalam aktivitas belajar sangat berguna untuk membangkitkan minat. Misalnya, belajar agar lulus ujian, menjadi juara, ahli dalam salah satu ilmu, memenuhi rasa ingin tahu, hingga mendapatkan gelar atau memperoleh pekerjaan. Dengan demikian, minat belajar tidak perlu berangkat dari nilai atau motivasi yang muluk-muluk.

Pendidikan inklusi adalah sebuah pelayanan pendidikan bagi peserta didik yang mempunyai kebutuhan pendidikan khusus di sekolah regular (SD, SMP, SMU, dan SMK) yang tergolong luar biasa; baik dalam arti kelainan, lamban belajar maupun berkesulitan belajar lainnya (Lay Kekeh Marthan, 2007: 145) Menurut Staub dan Peck (Tarmansyah, 2007: 83), pendidikan inklusi adalah penempatan anak berkelainan ringan, sedang, dan berat secara penuh di kelas. Hal ini menunjukkan kelas regular merupakan tempat belajar yang relevan bagi anakanak berkelainan, apapun jenis kelainannya. Dari beberapa pendapat tersebut, maka dapat ditarik kesimpulan bahwa pendidikan inklusi adalah pelayanan pendidikan untuk peserta didik yang berkebutuhan khusus tanpa memandang kondisi fisik, intelektual, sosial emosional, linguistik atau kondisi lainnya untuk bersama-sama mendapatkan pelayanan pendidikan di sekolah regular (SD, SMP, SMU, atau SMK).

Tujuan Pendidikan Inklusi secara umum adalah mewujudkan suasana belajar dan proses pembelajaran agar peserta didik secara aktif mengembangkan potensi pribadinya untuk memiliki kekuatan spiritual keagamaan, pengendalian diri, kepribadian, kecerdasan, akhlak mulia, dan keterampilan yang diperlukan dirinya, masyarakat, bangsa dan negara (UU No. 20 Tahun 2003, Pasal 1 Ayat 1). Oleh sebab itu, inti dari pendidikan inklusi adalah hak azasi manusia atas pendidikan. Suatu konsekuensi logis dari hak ini adalah semua anak mempunyai hak untuk menerima pendidikan yang tidak mendiskriminasikan dengan kecacatan, etnis, agama, bahasa, jenis kelamin, kemampuan, dan lain-lain. Tujuan praktis yang ingin dicapai dalam pendidikan inklusi meliputi tujuan langsung oleh anak, oleh guru, oleh orang tua, dan oleh masyarakat.

Pelaksanaan pembelajaran dalam kelas inklusif sama dengan pelaksanaan pembelajaran dalam kelas reguler. Namun jika diperlukan, anak berkebutuhan khusus membutuhkan perlakuan tersendiri yang disesuaikan dengan kondisi dan kebutuhan mereka. Untuk mengetahui kondisi dan kebutuhan anak berkebutuhan khusus maka diperlukan proses screening atau assessment. Bentuk intervensi pembelajaran bagi anak berkebutuhan khusus merupakan bentuk intervensi pembelajaran yang sesuai bagi mereka. Assessment yang dimaksud yaitu proses kegiatan untuk mengetahui kemampuan dan kelemahan setiap peserta didik dalam segi perkembangan kognitif dan perkembangan sosial melalui pengamatan yang sensitif.

Seorang pendidik hendaknya mengetahui program pembelajaran yang sesuai bagi anak berkebutuhan khusus. Pola pembelajaran yang harus disesuaikan dengan anak berkebutuhan khusus biasa disebut dengan Individualized Education Program (IEP) atau Program Pembelajaran Individual (PPI). Perbedaan karakteristik yang dimiliki anak berkebutuhan khusus membuat pendidik harus memiliki kemampuan khusus.

Sebelum Program Pembelajaran Individual dijalankan oleh pendidik, terlebih dahulu pendidik harus melakukan identifikasi terhadap kondisi dan kebutuhan anak berkebutuhan khusus agar diperoleh informasi yang akurat mengenai kebutuhan pembelajaran anak berkebutuhan khusus. Setelah proses screening atau assessment dilakukan dan kebutuhan anak berkebutuhan khusus teridentifikasi, maka Program Pembelajaran Individual (IEP) dapat dijalankan di kelas-kelas reguler. Program Pembelajaran Individual tersebut sebenarnya tidak mutlak diperlukan bagi anak berkebutuhan khusus dalam pembelajaran model inklusif di kelas reguler. Pada praktiknya, ada beberapa anak berkebutuhan khusus yang tidak memerlukan 
Aisah, S. Pd.

Upaya Meningkatkan Minat Belajar Anak Berkebutuhan Khusus Pada Kelas II SDN

Unggulan Melalui Metode Inklusi Penuh

Program Pembelajaran Individual. Mereka dapat belajar bersama dengan anak reguler dengan program yang sama tanpa perlu dibedakan.

Rumusan masalah dalam penelitian ini adalah untuk menjawab pertanyaan-pertanyaan: (1) Bagaimanakah proses pembelajaran anak berkebutuhan khusus (ABK) di Kelas II SDN Unggulan Kuningan?; dan (2) Apakah dengan menggunakan metode Full Inclusion akan terjadi peningkatan minat belajar pada Anak Berkebutuhan Khusus di kelas II SDN Unggulan Kuningan?

\section{METODE PENELITIAN}

Metode penelitian yang digunakan yaitu penelitian kualitatif berupa Penelitian Tindakan Kelas yang lazim kita kenal dengan Classrooom Action Research (Penelitian Tindakan Kelas). Metode penelitian ini dipilih karena mampu memberikan gambaran tentang perilaku siswa selama kegiatan belajar mengajar. Sutiyono (2005: 1) mengemukakan bahwa "metode penelitian kualitatif adalah metode penelitian yang digunakan untuk meneliti pada kondisi objek yang alamiah (sebagai lawannya adalah eksperimen) dimana peneliti adalah instrumen kunci, teknik pengumpulan data dilakukan secara triangulasi (gabungan), analisis data bersifat induktif dan hasil penelitian kualitatif yang lebih menekankan makna daripada generalisasi".

Lokasi penelitian dilakukan terhadap peserta didik kelas II di SD N Unggulan Kuningan. Hal tersebut dilakukan dengan alasan-alasan seperti: (1) Penulis merupakan tenaga pendidik di SDN Unggulan kuningan, dan merupakan guru/wali kelas II A; (2) Metode pembelajaran selama ini, terutama penerapan bagi anak ABK belum ada penelitianya. Subjek dalam penelitian kali ini adalah siswa ABK kelas II A SD N Unggulan Kuningan berjumlah tiga siswa. Karakteristik siswa di kelas ini memang berbeda-beda, dalam pelajaran matematika. Adapun siswa tersebut adalah:

Tabel 1. Identitas Siswa ABK

\begin{tabular}{lll}
\hline No & Nama & L/P \\
\hline $\mathbf{1}$ & Muhammad Rasyad Arif Nirwan & L \\
\hline $\mathbf{2}$ & Ruly Galih Pangestu & L \\
\hline $\mathbf{3}$ & Syahnur Iman & L \\
\hline
\end{tabular}

Menurut Moleong (2004: 236), "rancangan pada dasarnya merencanakan suatu kegiatan sebelum dilaksanakan". Rancangan ini adalah rancangan penelitian tindakan kelas (Classroom Action Research). Sebelum peneliti melakukan observasi tindakan lanjut, terlebih dahulu peneliti melakukan observasi tindakan kelas, yang mana hasilnya dituangkan dalam rancangan penelitian. Hal ini sesuai dengan kriteria penelitian tindakan kelas yaitu: "masalah penelitian yang harus dipecahkan berasal dari persoalan praktik pembelajaran di kelas". (Sugiyanto, 1997: 5).

Perencanaan penelitian menggunakan model spiral Kemmis \& Taggart (Wiraatmadja, 2005: 66). Dengan sistem model spiral refleksi yang dimulai dari rencana, tindakan, pengamatan, refleksi, perencanaan kembali merupakan dasar untuk suatu rancangan pemecahan permasalahan.

Tahap pertama dalam penelitian ini yaitu Plan (perencanaan) tindakan. Dalam tahap ini, peneliti menjelaskan tentang apa, mengapa, dimana, siapa, dan bagaimana tindakan penggunaan metode eksperimen tersebut dilakukan. Kegiatan ini dilakukan secara kolaborasi antara pihak yang melakukan tindakan (observer) dan pihak yang mengamati proses (peneliti) jalannya tindakan.

Tahap kedua dalam tindakan ini yaitu pelaksanaan tindakan (Action) yang merupakan implementasi isi rancangan. Dalam hal ini tentu saja penerapan metode Full Inclusion dalam mata pelajaran Matematika. 
Tahap ketiga yaitu kegiatan pengamatan (Observation). Observasi dilakukan pada saat proses diterapkannya tindakan, yaitu pada saat penerapan pembelajaran. Observasi ini dilakukan untuk mengumpulkan dan memperoleh data baik kinerja guru maupun aktivitas siswa selama proses pembelajaran berlangsung sebagai bekal untuk perbaikan data siklus berikutnya.

Tahap keempat adalah kegiatan Reflection (refleksi), yang mana merupakan kegiatan analisis, interpretasi, dan eksplanasi terhadap semua informasi yang diperoleh dari hasil observasi untuk mengemukakan kembali apa yang sudah dilakukan (kegiatan refleksi). Tahap ini dimaksudkan untuk mengkaji secara menyeluruh tindakan yang telah dilakukan, berdasarkan data yang telah terkumpul kemudian dilakukan evaluasi (dilakukan antara guru, peneliti, dan pihak lain yang terlibat) guna menyempurnakan tindakan selanjutnya pada siklus berikutnya.

Keempat tahap dalam penelitian tindakan tersebut merupakan satu siklus atau satu putarana Artinya, sesudah langkah ke empat, lalu kembali lagi ke pertama, dan seterusnya. Jadi, satu siklus adalah dimulai dari tahap penyusunan rancangan sampai dengan refleksi untuk melakukan evaluasi.

Analisis dalam penelitian dilakukan sejak sebelum memasuki kelas, selama di kelas, dan setelah selesai dari kelas. Analisis data dilakukan secara kualitatif, mengkategorikan dan mengklarifikasi berdasarkan analisis kemudian ditafsirkan dalam konteks keseluruhan permasalahan penelitian. Adapun langkah-langkah pengolahan data meliputi: (1) Kategori dan kodifikasi, yang mana data yang telah terkumpul kemudian diseleksi dan dihimpun sesuai dengan kerakteristiknya; (2) Reduksi data, data yang terkumpul di lapangan, setelah dikategorikan kemudian dikodifikasikan dalam laporan; (3) Klasifikasi data, untuk melihat gambaran data secara keseluruhan atau bagian-bagian tertentu.

\section{HASIL PENELITIAN DAN PEMBAHASAN}

Hasil Penelitian

Pada kondisi awal, cara pandang terhadap proses pembelajaran atau biasa dikenal dengan pendekatan pembelajaran (learning approach) yang digunakan oleh guru di sekolah adalah sesuai dengan kurikulum yang ada. Namun, untuk anak ABK di kelas II A khususnya, ada perbedaan perlakuan, perbedaan standar, dan tentunya perbedaan klaster di kelas. Hal tersebut tentunya akan berpengaruh terhadap psikologis anak secara tidak langsung. Seperti halnya, dalam hal posisi duduk, standar nilai, metode pengajaran, dan metode pembimbingan.

Berdasarkan hal tersebut, guru mencoba mengubah paradigma metode pengajaran guna meningkatkan minat belajar siswa ABK dalam pelajaran yang diteliti sekarang. Sebagaimana diketahui, bahwa siswa ABK yang ada di kelas II A jumlahnya ada 3 orang, yaitu:

Tabel 2. Klasifikasi Siswa ABK

\begin{tabular}{llcl}
\hline No & \multicolumn{1}{c}{ Nama } & L/P & Klasifikasi ABK \\
\hline $\mathbf{1}$ & Muhammad Rasyad Arif Nirwan & L & ADD \\
\hline $\mathbf{2}$ & Ruly Galih Pangestu & L & ADD \\
\hline $\mathbf{3}$ & Syahnur Iman & L & ADD \\
\hline
\end{tabular}

Proses perencanaan yang dilakukan dalam siklus ke-1 meliputi: (1) indetifikasi masalah dan perumusan masalah dengan bantuan teman sejawat; (2) menelaah kurikulum sebagai acuan dalam proses penelitian; (3) proses penyusunan RPP; (4) menyusun alat observasi; (5) menyiapkan alat bantu pembelajaran; (5) menyusun metode pembelajaran yang akan diberikan, evaluasi, dan intrumen tes.

Setelah melakukan perencanaan dan sebelum melakukan proses penelitian tindakan kelas, dilanjutkan dengan proses pelaksanaan. Adapun proses pelaksanaan tindakan kelas tersebut meliputi: (1) pengelolaan kelas; (2) guru melaksanakan apersepsi dan menyampaikan 
Aisah, S. Pd.

Upaya Meningkatkan Minat Belajar Anak Berkebutuhan Khusus Pada Kelas II SDN

Unggulan Melalui Metode Inklusi Penuh

tujuan pembelajaran yang akan diberikan; (3) guru menjelaskan dan mendemontrasikan materi yang akan diberikan; (4) siswa melakukan dan mendemonstrasikan semua materi yang diberikan oleh guru; (5) guru memberikan tindak lanjut; (6) siswa melakukan tes.

Proses pemberian materi pada siklus ke-1 ini dilakukan pada bulan Februari 2018. Kompetensi Dasar yang diajarkan adalah Materi Penjumlahan Matematika. Dari data hasil pengamatan di lapangan yang dilakukan oleh observer adalah sebagai berikut: (1) penelitian sudah berjalan dengan lancar sesuai dengan RPP yang telah dibuat sebelumnya; (2) Materi terfokus pada jenis latihan yang sedang diteliti; (3) siswa termotivasi pada materi yang diberikan oleh guru.

Tabel 3. Rekapitulasi Hasil Tes Siklus 1

\begin{tabular}{c|l|c|c}
\hline No & \multicolumn{1}{|c|}{ Uraian } & Hasil Siklus 1 & Persentase \\
\hline $\mathbf{1}$ & Jumlah Siswa yang Tuntas Belajar & $\mathbf{1 6}$ & $\mathbf{6 6 \%}$ \\
$\mathbf{2}$ & Tidak Tuntas & $\mathbf{8}$ & $\mathbf{3 4 \%}$ \\
\hline
\end{tabular}

Berdasarkan tabel di atas, dapat dijelaskan bahwa ketuntasan belajar siswa ada 15 siswa dari 24 siswa yang sudah tuntas belajar. Artinya, ada 8 siswa yang masih perlu bimbingan tambahan yang akan dibuat dalam siklus 2 nanti. Dari jumlah siswa yang tidak tuntas tersebut, 3 siswa ABK ada didalamnya. Bahkan, hasilnya berada paling bawah dari urutan nilai. Artinya, ketiga anak ABK ini mendapat nilai terkecil dari teman-temannya yang lain di Kelas II.

Tabel 4. Aktivitas Guru pada Pembelajaran Siklus 1

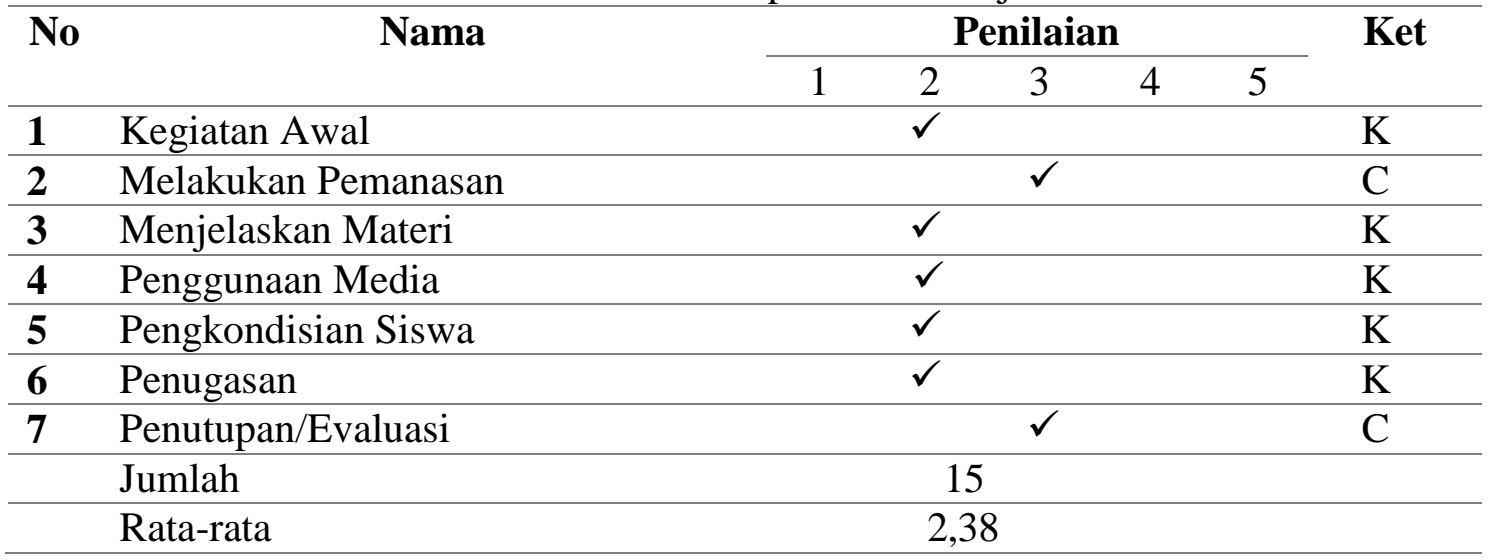

Aktivitas pembelajaran yang dilaksanakan oleh guru pada pertemuan 1 belum begitu memuaskan. Hal tersebut terlihat dengan perolehan nilai dari aspek penilaian yang hanya mencapai 2,38 dari skala nilai 1-5.

Berdasarkan data di atas, dapat disimpulkan bahwa aktivitas siswa dalam perbaikan pembelajaran yang dilaksanakan pada siklus 1 belum begitu memuaskan. Pada tahap ini akan dikaji apa yang telah terlaksana dengan baik dan yang masih kurang baik dalam proses belajar mengajar. Dari data-data yang telah diperoleh dapat duraikan sebagai berikut: (1) Selama proses belajar mengajar, guru telah melaksanakan semua pembelajaran dengan baik. Meskipun ada beberapa aspek yang belum sempurna, tetapi persentase pelaksanaannya untuk masingmasing aspek cukup besar; (2) Berdasarkan data hasil pengamatan diketahui bahwa siswa aktif selama proses belajar berlangsung; (3) Hasil belajar siswa pada siklus 1 belum mencapai ketuntasan, khususnya untuk siswa ABK yang ada di Kelas II A.

Proses perencanaan yang dilakukan dalam siklus ke-2 adalah sebagai berikut: (1) identifikasi masalah dan perumusan masalah dengan bantuan teman sejawat; (2) menelaah kurikulum sebagai acuan dalam proses penelitian; (3) proses penyusunan RPP; (4) menyusun alat observasi; (5) menyiapkan alat bantu pembelajaran; (6) menyusun metode pembelajaran yang akan diberikan, evaluasi, dan intrumen tes 
Setelah melakukan perencanaan, sebelum melakukan proses penelitian tindakan kelas, dilanjutkan dengan proses pelaksanaan. Adapun proses pelaksanaan tindakan kelas tersebut adalah sebagai berikut: (1) pengelolaan kelas; (2) guru melaksanakan apersepsi dan menyampaikan tujuan pembelajaran yang akan diberikan; (3) guru menjelaskan dan mendemontrasikan materi yang akan diberikan; (4) siswa melakukan dan mendemonstrasikan semua materi yang diberikan oleh guru; (5) guru memberikan tindak lanjut; (6) siswa melakukan tes formatif.

Proses pemberian materi pada siklus ke-2 ini dilakukan pada pertengahan Februari 2018. Dari data hasil pengamatan di lapangan yang dilakukan oleh observer adalah sebagai berikut: (1) penelitian sudah berjalan dengan lancar sesuai dengan RPP yang telah dibuat sebelumnya; (2) materi terfokus pada jenis latihan yang sedang diteliti; (3) siswa termotivasi pada materi yang diberikan oleh guru.

Tabel 5. Rekapitulasi Hasil Tes Siklus 2

\begin{tabular}{c|l|c|c}
\hline No & \multicolumn{1}{|c|}{ Uraian } & Hasil Siklus 2 & Persentase \\
\hline $\mathbf{1}$ & Jumlah Siswa yang Tuntas Belajar & $\mathbf{2 3}$ & $\mathbf{9 5 \%}$ \\
$\mathbf{2}$ & Tidak Tuntas & $\mathbf{1}$ & $\mathbf{5 \%}$ \\
\hline
\end{tabular}

Berdasarkan tabel di atas, diperoleh nilai formatif dari 24 siswa yang telah tuntas sebanyak 23 siswa dan tidak tuntas 1 orang. Maka secara klasikal ketuntasan belajar, hasil pada siklus 2 ini mengalami peningkatan lebih baik dari siklus 1 . Adanya peningkatan hasil belajar pada siklus 2 ini dipengaruhi oleh adanya peningkatan kemampuan guru dalam menerapkan pembelajaran metode Full Inclusion sehingga siswa menjadi lebih terbiasa dengan pembelajaran seperti ini dan siswa lebih mudah dalam memahami materi yang telah diberikan. Pada siklus 2 ketuntasan secara klasikal telah tercapai, sehingga penelitian ini hanya sampai pada siklus ini.

Tabel 6. Aktivitas Guru pada Pembelajaran Siklus 2

\begin{tabular}{|c|c|c|c|c|c|c|c|}
\hline \multirow[t]{2}{*}{ No } & \multirow[t]{2}{*}{ Nama } & \multicolumn{5}{|c|}{ Penilaian } & \multirow[t]{2}{*}{ Ket } \\
\hline & & 1 & 2 & 3 & 4 & 5 & \\
\hline $\mathbf{1}$ & Kegiatan Awal & & & & $\checkmark$ & & B \\
\hline 2 & Melakukan Pemanasan & & & & $\checkmark$ & & B \\
\hline 3 & Menjelaskan Materi & & & & $\checkmark$ & & $\mathrm{B}$ \\
\hline 4 & Penggunaan Media & \multicolumn{5}{|c|}{$\checkmark$} & $\mathrm{C}$ \\
\hline 5 & Pengkondisian Siswa & \multicolumn{5}{|c|}{$\checkmark$} & $\mathrm{C}$ \\
\hline 6 & Penugasan & \multicolumn{5}{|c|}{$\checkmark$} & B \\
\hline 7 & Penutupan/Evaluasi & \multicolumn{5}{|c|}{$\checkmark$} & B \\
\hline & Jumlah & \multicolumn{5}{|c|}{23} & \\
\hline & Rata-rata & \multicolumn{5}{|c|}{4,34} & \\
\hline
\end{tabular}

Aktivitas pembelajaran yang dilaksanakan oleh guru pada pertemuan 1 belum begitu memuaskan. Hal tersebut terlihat dengan perolehan nilai dari aspek penilaian yang hanya mencapai 4,34 dari skala nilai 1-5.

Pada tahap ini akan dikaji apa yang telah terlaksana dengan baik dan yang masih kurang baik dalam proses belajar mengajar melalui penerapan pembelajaran metode Full Inlusion. Dari data-data yang telah diperoleh dapat duraikan sebagai berikut: (1) selama proses belajar mengajar guru telah melaksanakan semua pembelajaran dengan baik. Meskipun ada beberapa aspek yang belum sempurna, tetapi persentase pelaksanaannya untuk masing-masing aspek cukup besar; (2) berdasarkan data hasil pengamatan diketahui bahwa siswa aktif selama proses belajar berlangsung; (3) kekurangan pada siklus-siklus sebelumnya sudah mengalami perbaikan dan peningkatan sehingga menjadi lebih baik; (4) hasil belajar siswa pada siklus 2 mencapai ketuntasan. 
Aisah, S. Pd.

Upaya Meningkatkan Minat Belajar Anak Berkebutuhan Khusus Pada Kelas II SDN

Unggulan Melalui Metode Inklusi Penuh

Pembahasan

Melalui hasil peneilitian ini, ditunjukkan bahwa pembelajaran metode Full Inclusion memiliki dampak positif dalam meningkatkan minat belajar siswa ABK. Hal ini dapat dilihat dari semakin mantapnya minat belajar siswa ABK terhadap materi yang disampaikan guru (ketuntasan belajar meningkat dari siklus 1 dan 2) yaitu masing-masing $0 \%$ dan $70 \%$, dari 3 siswa ABK yang ada di Kelas II A, 2 diantaranya telah mencapai ketuntasan, 1 orang belum mencapai. Namun, siswa tersebut secara kuantitas telah mengalami kenaikan nilai, walaupun belum mencapai KKM yang inginkan. Secara keseluruhan rata-rata kelas, presentasi ketuntasannya pada siklus 1 adalah $64 \%$ dan pada siklus ke 2 adalah $95 \%$.

Berdasarkan analisis data, diperoleh aktivitas siswa dalam proses pembelajaran metode Full Inclusion dalam setiap siklus mengalami peningkatan. Hal ini berdampak positif terhadap prestasi belajar siswa yaitu dapat ditunjukkan dengan meningkatnya nilai rata-rata siswa pada setiap siklus.

Berdasarkan analisis data, diperoleh aktivitas siswa dalam proses pembelajaran bahwa siswa senantiasa mendengarkan/memperhatikan penjelasan guru dan diskusi antar siswa/antara siswa dengan guru. Jadi, dapat dikatakan bahwa aktivitas siswa dikategorikan "aktif". Sedangkan untuk aktivitas guru selama pembelajaran telah melaksanakan langah-langkah pembelajaran metode Full Inclusion dengan baik. Hal ini terlihat dari aktivitas guru yang muncul diantaranya aktivitas membimbing dan mengamati siswa dalam mengerjakan kegiatan LKS/menemukan konsep, menjelaskan/melatih menggunakan alat, memberi umpan balik/evaluasi/tanya jawab dimana persentase untuk aktivitas di atas cukup besar.

\section{SIMPULAN DAN SARAN}

Simpulan

Berdasarkan hasil penelitian dapat ditarik kesimpulan sebagai berikut: (1) keberhasilan dari penggunaan metode Inklusi Penuh bagi anak-anak ABK di kelas II A SD N Unggulan Kuningan, dalam pembelajaran Matematika terjadi peningkatkan minat belajar siswa berkebutuhan khusus (ABK); (2) hasil belajar siswa dalam memahami pembelajaran Matematika secara individu dan kelompok pada proses pembelajaran meningkat pada siklus-1 sebesar $66 \%$ meningkat menjadi $95 \%$ pada siklus 2 . Hal tersebut berarti dari Kategori Cukup Baik pada siklus 1 meningkat menjadi kategori Baik pada siklus 2; (3) terjadi peningkatan minat belajar siswa ABK dengan menggunakan metode Inklusi Penuh di Kelas II A. Hal tersebut dibuktikan dengan terjadinya peningkatan hasil belajar siswa ABK di Kelas II A.

\section{Saran}

Berdasarkan kesimpulan dari penelitian di atas maka peneliti menyarankan sebagai berikut: (1) bagi guru, sebaiknya selalu menambah pengetahuan dan wawasan agar dapat meningkatkan pembelajarannya, terutama selalu berinovasi sehingga dapat meningkatkan profesionalismenya; (2) bagi sekolah, diharapkan selalu memberikan layanan yang terbaik bagi pelaksanaan pembelajaran dengan upaya menyediakan sarana yang sangat ditentukan siswa untuk memperlancar proses belajarnya, begitu pula dengan sarana yang dibutuhkan bagi siswa ABK; (3) bagi siswa, agar lebih bersemangat dan bersungguh-sungguh mengikuti pelajaran; (4) bagi orang tua siswa yang putranya memiliki kebutuhan khusus, jangan berkecil hati, karena sekolah inklusi berusaha memberikan pelayanan terbaik bagi siswa-siswinya yang bersekolah di sekolah inklusi. 


\section{DAFTAR PUSTAKA}

Ahmadi, Abu. (1998). Didaktik metodik. Semarang: CV. Toha Putra.

Baihaqi \& Sugiarmin. (2006). Memahami dan membantu anak ADHD. Bandung: PT. Refika Aditama.

Buchari. (1985). Psikologi pendidikan. Jakarta. Aksara Baru.

Gie. (1995). Cara belajar yang efisien. Yogyakarta: Liberti.

Hallahan, Daniel P., dkk. (2009). Exceptional learners: an introduction to special education. Boston: Pearson Education Inc.

Hardjana. (1994). Kiat sukses di Perguruan Tinggi. Yogyakarta: Kanisius.

Kartono, K. (1995). Bimbingan belajar di SMU dan Perguruan Tinggi. Jakarta: Raja Grafindo Persada.

Loekmono. (1994). Belajar bagaimana belajar. Jakarta: BPK Gunung Mulia.

Peraturan Menteri Pendidikan Nasional Nomor 70 Tahun 2009 Tentang Pendidikan Inklusif Bagi Peserta Didik yang Memiliki Kelainan dan Memiliki Potensi Kecerdasan dan/atau Bakat Istimewa.

Slameto. (1995). Belajar dan faktor-faktor yang mempengaruhinya. Jakarta: Rineka Cipta.

Sudarmono. (1994). Tuntunan metodologi belajar. Jakarta: Grasindo.

Wardani, I.G.A.K., Julaeha, S., \& Marsinah N. (2008). Penelitian tindakan kelas. Jakarta: Universitas Terbuka. 